\title{
A vértranszfúzió gyakorisága primer csípőprotézis-beültetés után
}

\author{
Skaliczki Gábor dr. ${ }^{1}$ - Szatmári Attila dr. ${ }^{1}$ - Sallai Imre dr. ${ }^{1}$ \\ Antal Imre dr. ${ }^{1}$ - Kiss Balázs dr. ${ }^{3}$ - Bejek Zoltán dr. ${ }^{1}$ - Holnapy Gergely dr. ${ }^{1}$ \\ Major Tibor dr. ${ }^{1}$. Czirók Gábor dr. ${ }^{2}$. Terebessy Tamás dr. ${ }^{1}$ \\ ${ }^{1}$ Semmelweis Egyetem, Általános Orvostudományi Kar, Ortopédiai Klinika, Budapest \\ ${ }^{2}$ Csongrád Megyei Egészségügyi Ellátó Központ, Makói Intézmény, Baleseti Sebészeti Osztály, Makó \\ ${ }^{3}$ Semmelweis Egyetem, Általános Orvostudományi Kar, Biofizikai és Sugárbiológiai Intézet, Budapest
}

Bevezetés: Csípőprotézis-beültetés után gyakran van szükség vértranszfúzióra, mely esetenként komoly mellékhatásokkal járhat, nehezen hozzáférhető és költséges.

Célkitüzés: Munkánk célja az volt, hogy megvizsgáljuk, saját gyakorlatunkban milyen gyakran van szükség primer csípőprotézis-beültetés során vérátömlesztésre, és ennek gyakoriságát mely tényezők befolyásolják.

Módszer: Vizsgálatunkban 210, csípóprotézis-beültetésen átesett beteg anyagát dolgoztuk fel. Feljegyeztük a mütét előtti hemoglobin- és hematokritértékeket, a betegek életkorát, nemét, testtömegindexét, a beültetett protézis típusát, a drénhasználatot, valamint a perioperatív időszakban használt véralvadásgátló és a műtét során alkalmazott vérzéscsökkentő szereket. Az adatokat összevetettük az alkalmazott transzfúzió mennyiségével és típusával.

Eredmények: Összesen a betegek 41\%-a kapott vérkészítményt, az allogén transzfúzió aránya 8,6\% volt. Az autotranszfúziós betegek nem igényeltek allogénvér-átömlesztést. A transzfúziós igény függött a preoperatív hemoglobin- és hematokritértékektől, a protézis típusától, a drénhasználattól és a vérzéscsillapító szerek használatától. A vérátömlesztés mennyisége nem mutatott összefüggést a betegek nemével és testtömegindexével.

Következtetés: Vizsgálatunk alapján allogén vér transzfúziójára az esetek kevesebb mint 10\%-ában van szükség primer csípőprotézis-beültetés során. A vérátömlesztést a leginkább a preoperatív hemoglobin- és hematokritértékek, valamint az alkalmazott, fibrinolízist gátló szerek befolyásolják. Az autotranszfúzió alkalmas módszer az allogénvér-átömlesztés elkerülésére.

Orv Hetil. 2020; 161(8): 290-294.

Kulcsszavak: csípóprotézis-beültetés, vérátömlesztés, tranexámsav

\section{Prevalence of blood transfusion after primary total hip arthroplasty}

Introduction: Total hip arthroplasty is one of the most common surgical procedures that requires blood transfusion, with the possible risk of significant complications.

Aim: A retrospective study was performed to analyze the predictors of blood transfusion after primary total hip arthroplasty.

Method: We collected the data of 210 consecutive patients undergoing total hip arthroplasty. Patient's data, preoperative hemoglobin and hematocrit level, the type of the prosthesis, the use of a suction drain, tranexamic acid or anticoagulants and the type and amount of blood transfusion were recorded.

Results: A total of $41 \%$ of our patients required transfusion, $8.6 \%$ receiving allogenic blood. Significant predictors of allogenic blood transfusion were preoperative hemoglobin and hematocrit levels, the type of prosthesis, the use of suction drainage and the use of tranexamic acid. Patients with pre-donated autologous blood did not require allogenic blood transfusion.

Conclusion: Based on our study, total hip arthroplasty necessitates allogenic blood transfusion in 8.6\%. Major predictors associated with the need for transfusion are preoperative hemoglobin and hematocrit levels, the type of prosthesis, the use of suction drainage and the use of tranexamic acid. Pre-donated autologous blood helps to reduce allogenic transfusion rate.

Keywords: total hip arthroplasty, blood transfusion, tranexamic acid

Skaliczki G, Szatmári A, Sallai I, Antal I, Kiss B, Bejek Z, Holnapy G, Major T ${ }^{\dagger}$, Czirók G, Terebessy T. [Prevalence of blood transfusion after primary total hip arthroplasty]. Orv Hetil. 2020; 161(8): 290-294.

(Beérkezett: 2019. augusztus 18.; elfogadva: 2019. szeptember 28.) 


\section{Rövidítések}

$\mathrm{BMI}=($ body mass index $)$ testtömegindex; TAG = thrombocytaaggregáció-gátló

A csípőprotézis-mútétek mai formájukban több mint ötven éve léteznek. Köszönhetően az általuk biztosított kiemelkedő életminőség-javulásnak, a sebészi technika, a protézisipar, valamint a társszakmák fejlödésének, a beültetések száma mind nemzetközi, mind hazai szinten folyamatosan emelkedik [1]. A mütétek gyakran járnak komolyabb vérvesztéssel, ami az esetek egy részében transzfúziót tesz szükségessé [2]. Jelentős erőfeszítések történnek azért, hogy a transzfúziós igény csökkenjen [3], ennek ellenére a csípő- és térdprotézis-beültetések a 10 leggyakrabban transzfúziót igénylő beavatkozás közé tartoznak [4]. A protézismútétek nagy száma miatt a sebészeti betegek közül térd- és csípőprotézis-beültetés után van a leggyakrabban szükség transzfúzióra, így az összes kórházi betegnek adott vérátömlesztés 8 százaléka ezeknél a betegeknél történik [5].

A vérátömlesztésnek különböző módszerei ismertek nagyízületi protézisműtétek során. Lehetőség van a preoperatív időszakban levett autológ vér visszaadására; közvetlenül a mütét előtt hemodilúciót követően levett autológ vér transzfúziójára; a mütéti területről szívóval eltávolított vérből speciális szûrőberendezés (cell saver) segítségével összegyưjjtött vörösvértest-koncentrátum visszaadására, a mútét után a sebváladékból visszanyert vörösvértest-koncentrátum beadására; vagy allogén vér átömlesztésére.

A transzfúziók számának lehetőség szerinti csökkentését több tényező indokolja. Vérátömlesztés során számos szövődmény alakulhat ki, melyek közül főként az allogén transzfúzióval kapcsolatos komplikációk ismertek: előfordulhat hemolízis, anafilaxiás reakció, vese- és tüdőkárosodás [6], esetleg felléphetnek ma még nem ismert, vérrel átvihető kórokozók következtében kialakuló betegségek. További nehézséget jelent az allogén vérkészlet korlátozott volta, valamint a költségessége. Az autotranszfúzió adása sem veszélytelen. Autológvér-donorok körében tizenkétszer gyakrabban fordul elő hospitalizáció, mint allogénvér-adóknál, valamint a vércsoporttévesztés előfordulásának valószínűsége is jelentősen nagyobb, ahogy bakteriális kontamináció is gyakrabban fordul elő [7]. Emellett ha nem megfelelő időzítéssel történik a mútét előtt a saját vér levétele, akkor előfordulhat, hogy a levett vérmennyiség miatt alacsony hemoglobinértékről indulnak a betegek, így gyakrabban szorulnak mütét után allogén transzfúzióra. A saját vér levételéhez kapcsolódó laborvizsgálatok, valamint a vér tárolása ráadásul jelentős költséget jelentenek, ennek ellenére az így levett vér 44-45\%-a nem kerül felhasználásra [7]. A cell saver, vagy a sebváladékból vörösvértestkoncentrátumot leszúrő vérvisszaadó készülék használata szintén jelentős költséggel bír, így indokolt lenne a vérátömlesztések számát lehetőség szerint csökkenteni.
Munkánk célja az volt, hogy meghatározzuk saját beteganyagunkban a primer csípóprotézis-beültetés során fellépő transzfúziós igényt, megvizsgáljuk, hogy a vérátömlesztés melyik formáját milyen gyakorisággal használjuk, valamint felmérjük az ezt befolyásoló tényezőket.

\section{Módszer}

Prospektív, monocentrikus vizsgálatunkba a Semmelweis Egyetem Ortopédiai Klinikáján egymás után operált betegeket vontunk be, akiknél elektív csípőprotézis-beültetés történt primer (idiopátiás) csípőízületi arthrosis miatt. Betegeinknél a vérpótlás három formáját alkalmaztuk. Azoknál, akik életkoruk és társbetegségeik alapján erre alkalmasak voltak, 2 egység autotranszfúziót vettünk le a mütét előtt, és amennyiben ez a mütét után szükségessé vált, visszaadtuk nekik. Ha az operatőr úgy ítélte meg, a beavatkozás után a mûtéti területet drenáló csőre speciális gyưjtőzsák került (Bellovac ABT, Wellspect, Mölndal, Svédország), mely az elvezetett sebváladékból speciális szúrővel kiválasztja a vörösvértesteket, s azok így visszaadhatók a betegnek. Azoknál a betegeknél, akiknél egyik eddig felsorolt módszer sem állt rendelkezésre, vérigény esetén választott allogén vörösvértest-koncentrátumot adtunk. Minden beteg, akinél belgyógyászati állapota alapján nem volt kontraindikált, a mútét során tranexámsavat kapott (15 mg/testsúlykg dózisban), mely az ortopéd sebészetben mára már elterjedten használt, a fibrinolízis gátlása révén jelentős vérzéscsökkentő hatással rendelkező gyógyszer [8].

Rögzítettük a vizsgálatunkba bevont betegek demográfiai adatait, nemét, testsúlyát, valamint testtömegindex (BMI)-értékét. Feljegyeztük, hogy milyen típusú protézis (cementes vagy cement nélküli rögzítésű) került beültetésre, hogy történt-e drénhasználat, emellett feldolgoztuk a következő adatokat is: a preoperatív és posztoperatív hemoglobin- és hematokritértékeket, a krónikusan szedett gyógyszereket, különös tekintettel a véralvadásgátló szerekre (K-vitamin-antagonisták, thrombocytaaggregáció-gátlók, alacsony molekulasúlyú heparinszármazékok stb.). Feljegyeztük a mútét során esetlegesen alkalmazott tranexámsav használatát. A transzfúziós igényt a kórházi bennfekvés ideje alatt vizsgáltuk. Megfigyeltük, hogy a betegek igényeltek-e, és ha igen, milyen mennyiségben és milyen típusú transzfúziót. Megvizsgáltuk, hogy kialakult-e a mütéttel vagy a transzfúzióval kapcsolatban szövődmény, valamint hogy a transzfúziós igény és az alkalmazott transzfúzió menynyisége összefüggésben áll-e bármelyik, előbb felsorolt tényezővel.

\section{Betegek}

Munkánkba 210 beteget vontunk be, akiknél primer coxarthrosis miatt csípőprotézis-beültetést végeztünk. Betegeink átlagéletkora 67 év volt (27-86 év), 72 férfi és 138 nő alkotta a vizsgálati csoportot. A BMI átlagosan 
28 (17-44), az átlagos testsúly $78 \mathrm{~kg}(42-125 \mathrm{~kg})$ volt. 172 esetben cementes csípóprotézis-beültetést végeztünk, 32 esetben cement nélküli, míg 6 esetben hibrid rögzítést alkalmaztunk. A mütét során az átlagos hemoglobinesés $27 \mathrm{~g} / 1$ volt. Thrombocytaaggregáció-gátlót 26 betegünk (12\%) szedett, egy beteg a mútét előtti időszakban kumarinterápiát, egy másik rivaroxabankezelést kapott, így véralvadásgátló kezelésben összesen 28 beteg (13\%) részesült. A mütétek során 156 esetben (74\%) használtunk tranexámsavat vérzéscsillapítás céljából, 54 esetben (26\%) nem. 138 betegnél (67\%) került behelyezésre a mütét után szívódrén, 72 betegnél (33\%) nem használtunk drént.

\section{Statisztikai értékelés}

A statisztikai elemzést GraphPad Prism 6 (GraphPad Software, Inc., San Diego, CA, Amerikai Egyesült Államok [USA]) és Microsoft Excel 2013 (Microsoft, Redmond, WA, USA) szoftverekkel végeztük. A leíró statisztikai adatokat átlag \pm standard hiba formátumban adtuk meg, az ettől eltérő formátumot külön jeleztük. A vizsgálati csoportok közötti eltérést a $\mathrm{p}<0,05$ valószínűségérték esetén tekintettük szignifikánsnak. Normál eloszlású valószínűségi változók vizsgálatára kétmintás t-próbát végeztünk; a szórásnégyzetek azonosságát F-próbával vizsgáltuk, eltérő szórásnégyzeteknél Welch-féle korrekciót alkalmaztunk. Nem normál eloszlású változók esetében Mann-Whitney-próbát végeztünk. A kategoriális változók vizsgálatakor kontingenciatáblázatokat készítettünk, majd az elméletileg várható és megfigyelt eloszlás közötti eltérést khi-négyzet-próbával teszteltük.

\section{Eredmények}

A mütétek után 124 esetben (trafo- csoport, 59\%) nem volt szükség vérpótlásra. Transzfúzióra összesen 86 beteg szorult (trafo+ csoport, 41\%), akik közül $16(7,6 \%)$ kapott kizárólag allogén transzfúziót, 30 (14,3\%) beteg kapott vissza vérvisszaadó készülékből vörösvértest-koncentrátumot, míg 34 (16,2\%) betegnél a mútét előtt levett saját vér visszaadása történt meg. 2 beteg (1\%) a vérvisszaadó rendszerből származó vérpótlás mellé kapott allogén transzfúziót is, további 4 beteg $(1,9 \%)$ autotranszfúzió mellett kapott vérvisszaadóból származó vörösvértest-koncentrátumot. Összességében betegeink 8,6\%-a kapott allogén vérkészítményt. Az átlagosan beadott vér mennyisége $324 \mathrm{ml}$ volt, vérvisszaadóból átlagosan $216 \mathrm{ml}$ vörövértest-koncentrátumban részesültek betegeink.

Az általunk vizsgált változók közül a transzfúzió ténye nem függött össze a testsúllyal $(77,83 \pm 1,434$ vs. 77,73 $\pm 1,76, \mathrm{p}=0,97)$, a BMI-vel $(28,36 \pm 0,437$ vs. $28,09 \pm$ $0,507, \mathrm{p}=0,68$ ), a nemmel (trafo+ csoport: $65,12 \%$ nő vs. $34,88 \%$ férfi, trafo- csoport: $66,13 \%$ nő vs. $33,87 \%$ férfi, $\mathrm{p}=0,88)$ vagy a thrombocytaaggregáció-gátló (TAG-) szerek szedésével (trafo+ csoport: 16,28\% TAG+ vs. $83,72 \%$ TAG-; trafo- csoport: $11,29 \%$ TAG+ vs. $88,71 \%$ TAG-, $\mathrm{p}=0,30)$.

Vizsgálatunk alapján a vérigény függött az életkortól: az összes vérátömlesztést kapott beteget vizsgálva, az életkor szignifikánsan alacsonyabb volt a transzfúziót nem igénylő betegeknél, mint a vérátömlesztésben részesülőknél $(65 \pm 1,43$ vs. $76 \pm 1,55$ év, $p=0,0273)$. Az összes beteget vizsgálva a preoperatív hemoglobinértékek szignifikánsan magasabbak voltak a vérpótlást nem igénylő csoportban $(138,8 \pm 1,363 \mathrm{mg} / \mathrm{l}$ vs. $134,3 \pm$ 1,639 mg/l, p = 0,0337), a hematokritértékek azonban nem különböztek jelentősen egymástól a két csoport között $(0,417 \pm 0,003$ vs. $0,405 \pm 0,004, p=0,0516)$. Amennyiben azokat a betegeket vizsgáltuk, akiknél allogén transzfúzióra került sor, mind a hemoglobin-, mind a hematokritértékek szignifikánsan magasabbak voltak a vérátömlesztést nem igénylő csoportban, mint a transzfúzióra szoruló betegeknél $(138,8 \pm 1,363 \mathrm{mg} / \mathrm{l}$ vs. $128,7 \pm 3,812 \mathrm{mg} / \mathrm{l}, \mathrm{p}=0,0113 ; 0,41 \pm 0,003$ vs. 0,38 $\pm 0,013, \mathrm{p}=0,0189)$.

Vérpótlásra cement nélküli protézis használata mellett gyakrabban volt szükség, mint cementes protézis beültetésekor (trafo+ csoport: $27,06 \%$ cement nélküli vs. $72,94 \%$ cementes, trafo- csoport: 9,76\% cement nélküli vs. $90,24 \%$ cementes, $\mathrm{p}=0,001)$. A transzfúziót igénylő betegeknél 80,23\%-ban történt drénhasználat és 19,77\%ban nem, míg a vérátömlesztést nem kapó betegeknél ez az arány $55,65 \%$ drénhasználatot és $44,35 \%$ drén nélküli mútétet jelentett, így összességében szívó használata esetén szignifikánsan gyakrabban fordult elő transzfúzió $(\mathrm{p}=0,0002)$. A tranexámsav használata szignifikánsan csökkentette a mútét utáni vérigényt (trafo+ csoport: $63,95 \%$ tranexám+ vs. $36,05 \%$ tranexám-; trafo- csoport: $79,84 \%$ tranexám+ vs. $20,16 \%$ tranexám-, p = $0,0104)$.

\section{Megbeszélés}

Munkánk alapján primer arthrosis miatt végzett elektív csípőprotézis-beültetések után a betegek 8,6\%-a szorult allogénvér-átömlesztésre. Allogén vér adására gyakrabban került sor alacsony preoperatív hemoglobin- és hematokritértékek esetén, cement nélküli protézisek beültetésekor, valamint drén használata mellett. A mütét alatt alkalmazott tranexámsav csökkentette a vérigényt. Az összes transzfúzió tekintetében a fiatalabb betegek gyakrabban részesültek vérátömlesztésben. Nem befolyásolta a vérátömlesztés szükségességét a betegek neme, testsúlya, BMI-je vagy az, hogy szedtek-e a mütét előtt véralvadásgátló gyógyszereket.

Az összes transzfúziós igény betegeink esetében $41 \%$ volt, míg allogén vér átömlesztésére 8,6\%-ban volt szükség. Yoshihara az USA 10 éves csípőprotézises beteganyagát tekintette át, így rendkívül jelentős számú, közel 1800000 esetet elemezve azt találta, hogy allogén transzfúzióra 16,4\%-ban került sor, az összes vérátömlesztés aránya pedig 25,5\%-nak bizonyult [7]. Saját ered- 
ményeink azért különbözhetnek ezektől az adatoktól, mert nagyon jelentős a betegszámok közötti eltérés. Másrészt mi az esetek 74\%-ában alkalmaztunk tranexámsavat, melynek használata a Yoshihara által vizsgált 10 éves periódusban (2000-2009) még nem volt általános. Ugyancsak árnyalja a képet, hogy Yoshihara a munkájában nem vizsgálta a posztoperatív sebváladék szűrésének segítségével történő vérpótlást. Ha ezeket az eseteket nem számoljuk bele a saját beteganyagunkba, akkor a teljes transzfúziós ráta $24,8 \%$, mely megfelel az általa közölt 25,5\%-nak.

Az irodalom alapján a transzfúziós igényt több tényező befolyásolja. Elsősorban a preoperatív hemoglobinszint, emellett a testsúly, az életkor, a mútéti vérveszteség, a társbetegségek, egyes gyógyszerek szedése (például TAG-szerek), a mútét előtti alacsony thrombocytaszám, valamint a női nem [9-11].

Saját anyagunkban azok a betegek, akiknél a mütét előtt történt autológ vér levétele, nem igényeltek allogén transzfúziót, a saját vér visszaadása elegendő volt a mütét utáni anaemia rendezésére. Ez az eredmény megfelel a Forgie, valamint Goldman és mtsai korábbi közleményében leírtakkal $[12,13]$, ahol mindketten arról számoltak be, hogy a preoperatív időszakban deponált és a mütét után visszaadott saját vér csökkenti a posztoperatív allogén transzfúzió szükségességét. Yoshihara korábban idézett munkájában szintén azt tapasztalta, hogy az autotranszfúziós betegek allogénvér-igénye alacsonyabb, mint a saját vér levétele nélkül operált betegeké [7].

A magasabb életkorral rendszerint együtt járó szív- és érrendszeri, valamint egyéb keringési betegségek hatása a mütét utáni anaemia következtében felerősödhet, emiatt idős betegek gyakrabban részesülnek allogén transzfúzióban [14]. Saját beteganyagunkban az összes vérátömlesztést tekintve a fiatalabb életkor gyakoribb vérátömlesztéssel párosult, azonban a kizárólag allogén transzfúzióban részesülők átlagos életkora a mi anyagunkban is magasabb volt, mint a többi betegé (67 vs. 63 év). Ez az eltérés azzal magyarázható, hogy az autológ vér levételét a jelenlegi gyakorlatunk alapján kizárólag 70 év alatti betegeknél végezzük el, így az autotranszfúziós csoport fiatalabb betegekből áll. Ráadásul az autológ vér, amennyiben nem kerül beadásra, más betegnek nem adható oda, ezért a kezelőorvosok kevésbé indokolt esetben is hajlamosak azt a betegnek visszaadni. Ez az - egyébként némileg kifogásolható - gyakorlat vezet oda, hogy az összes transzfúzió tekintetében a betegek átlagéletkora alacsonyabb, míg a kizárólag allogénvér-átömlesztésben részesülő betegek idősebbek.

$\mathrm{Az}$ alacsony, mütét előtti hemoglobin- és hematokritszint gyakoribb allogénvér-átömlesztéssel jár együtt. Keating és mtsai vizsgálata alapján ez még azoknál a betegeknél is így van, akiknél a mütét előtt autotranszfúzió levétele történt [15]. Faris közleménye szerint azoknak a betegeknek, akiknek a mütét előtti hemoglobinértéke 10-13 g/l között van, kétszeres az esélye vérátömlesztésre, mint azoknak, akiknél ez az érték 13 g/l felett van
[10]. Saját vizsgálatunkban ugyanezt tapasztaltuk: az összes beteget vizsgálva a preoperatív hemoglobinértékek szignifikánsan magasabbak voltak a vérpótlást nem igénylő csoportban. A hematokritértékek esetén nem találtunk hasonló összefüggést az összes beteget vizsgálva, azonban ha kizárólag az allogén transzfúzióra szoruló betegek csoportját elemeztük, akkor mind a hemoglobin-, mind a hematokritértékek szignifikánsan magasabbak voltak a vérátömlesztést nem igénylő csoportban, mint a transzfúzióra szoruló betegeknél. Ennek oka szintén az lehet, hogy az autotranszfúziót akkor is megkapták a betegek, ha állapotuk azt nem feltétlenül tette szükségessé.

A szakirodalom nem egységes annak megítélésében, hogy a BMI milyen szerepet játszik a protézismútétek körüli vérveszteségben. Carling és mtsai az közölték, hogy az alacsonyabb BMI-érték fokozza a vérveszteség kockázatát [16], Bowditch vizsgálata alapján nagyobb a vérvesztés túlsúlyos betegeknél [17], ugyanakkor Hrnack és munkacsoportja nem talált összefüggést a BMI és a vérveszteség között [18]. Park több mint 11000 beteg anyagát áttekintve szintén nem talált jelentős öszszefüggést a BMI és a vérveszteség között [11]. Saját beteganyagunkban mi sem találtunk kapcsolatot a BMI és a transzfúziós igény között.

A nem tekintetében szintén ellentmondásosak az adatok, Yoshihara közleménye alapján a nők szorulnak gyakrabban transzfúzióra [7], míg Park vizsgálataiban a férfiak esetében mértek nagyobb vérveszteséget [11]. Jelen munkánkban nem találtunk összefüggést a nem és a transzfúziós igény között.

A protézis rögzítése és a mútét utáni vérveszteség között hosszú ideje ismert az összefüggés [19]. Cementes rögzítésű protézisek használata esetén kisebb a vérveszteség, ugyanis a csontcement a csont-protézis közötti rés lezárásával jelentősen csökkenti a velőüregből származó, így a teljes posztoperatív vérzést. Ezt igazolta vizsgálatunk is: a cement nélküli protézisek után gyakrabban volt szükség transzfúzióra. A mütét utáni szívóhasználatot kiterjedten vizsgálták az elmúlt időszakban, nagy betegszámon végzett metaanalízisek, de saját munkacsoportunk korábbi vizsgálatai is igazolták, hogy a drén használata nem befolyásolja a mútét utáni vérzéses, fertőzéses, sebgyógyulással kapcsolatos szövődményeket, azonban drén használata mellett gyakrabban van szükség vérátömlesztésre [20-22]. Beteganyagunkat áttekintve azt tapasztaltuk, hogy a szívó használata fokozta a transzfúziós igényt. A tranexámsav perioperatív vérzéscsökkentő hatása jól ismert az irodalomból [23], ezt a tapasztalatot saját vizsgálatunk is megerősítette.

\section{Következtetés}

Összefoglalva eredményeinket azt találtuk, hogy betegeink 8,6\%-a szorult idegen vér adására elektív primer csípőprotézis beültetése után. A mütét előtti alacsonyabb hemoglobin- és hematokritértékek, a protézis cement 
nélküli rögzítése, valamint a drén használata fokozta a transzfúziós igényt, a tranexámsav alkalmazása csökkentette azt. Nem befolyásolta a vérátömlesztések számát a betegek neme, testsúlya, BMI-je, valamint az, hogy szedtek-e a mütét előtt véralvadásgátló gyógyszereket. $\mathrm{Az}$ autotranszfúzió hatásos módszernek bizonyult az allogén transzfúzió elkerülésére.

Anyagi támogatás: A közlemény megírása és a kapcsolódó kutatómunka anyagi támogatásban nem részesült.

Szerzői munkamegosztás: S. G., T. T.: A hipotézisek kidolgozása. S. G., Sz. A., S. I., A. I., B. Z., H. G., C. G., M. T., T. T.: A vizsgálat lefolytatása. K. B.: Statisztikai elemzések. S. G., T. T.: A kézirat megszövegezése. A cikk végleges változatát valamennyi szerző elolvasta és jóváhagyta.

Érdekeltségek: A szerzőknek nincsenek a közlemény megírására hatással bíró érdekeltségeik.

\section{Irodalom}

[1] Kurtz S, Mowat F, Ong K, et al. Prevalence of primary and revision total hip and knee arthroplasty in the United States from 1990 through 2002. J Bone Joint Surg Am. 2005; 87: 14871497.

[2] Feagan BG, Wong CJ, Lau CY, et al. Transfusion practice in elective orthopaedic surgery. Transfus Med. 2001; 11: 87-95.

[3] Leahy MF, Mukhtar SA. From blood transfusion to patient blood management: a new paradigm for patient care and cost assessment of blood transfusion practice. Intern Med J. 2012; 42: 332-338.

[4] Morton J, Anastassopoulos KP, Patel ST, et al. Frequency and outcomes of blood products transfusion across procedures and clinical conditions warranting inpatient care: an analysis of the 2004 healthcare cost and utilization project nationwide inpatient sample database. Am J Med Qual. 2010; 25: 289-296.

[5] Wells AW, Mounter PJ, Chapman CE, et al. Where does blood go? Prospective observational study of red cell transfusion in north England. BMJ 2002; 325: 803.

[6] Squires JE. Risks of transfusion. Southern Med J. 2011; 104: 762-769

[7] Yoshihara H, Yoneoka D. National trends in the utilization of blood transfusions in total hip and knee arthroplasty. J Arthroplasty $2014 ; 29$ : 1932-1937.

[8] Xie J, Zhang S, Chen G, et al. Optimal route for administering tranexamic acid in primary unilateral total hip arthroplasty: Results from a multicenter cohort study. Br J Clin Pharmacol. 2019; 85: 2089-2097.
[9] Callaghan JJ, Spitzer AI. Blood management and patient specific transfusion options in total joint replacement surgery. Iowa Orthop J. 2000; 20: 36-45.

[10] Faris PM, Spence RK, Larholt KM, et al. The predictive power of baseline hemoglobin for transfusion risk in surgery patients. Orthopedics 1999; 22(1 Suppl): S135-S140.

[11] Park JH, Rasouli MR, Mortazavi SM, et al. Predictors of perioperative blood loss in total joint arthroplasty. J Bone Joint Surg Am. 2013; 95: 1777-1783.

[12] Forgie MA, Wells PS, Laupacis A, et al. Preoperative autologous donation decreases allogeneic transfusion but increases exposure to all red blood cell transfusion: results of a meta-analysis. International Study of Perioperative Transfusion (ISPOT) Investigators. Arch Intern Med. 1998; 158: 610-616.

[13] Goldman M, Savard R, Long A, et al. Declining value of preoperative autologous donation. Transfusion 2002; 42: 819-823.

[14] Nuttall GA, Santrach PJ, Oliver WC Jr, et al. The predictors of red cell transfusions in total hip arthroplasties. Transfusion 1996; 36: 144-149.

[15] Keating EM, Meding JB, Faris PM, et al. Predictors of transfusion risk in elective knee surgery. Clin Orthop Relat Res. 1998; 357: 50-59.

[16] Carling MS, Jeppsson A, Eriksson BI, et al. Transfusions and blood loss in total hip and knee arthroplasty: a prospective observational study. J Orthop Surg Res. 2015; 10: 48.

[17] Bowditch MG, Villar RN. Do obese patients bleed more? A prospective study of blood loss at total hip replacement. Ann R Coll Surg Engl. 1999; 81: 198-200.

[18] Hrnack SA, Skeen N, Xu T, et al. Correlation of body mass index and blood loss during total knee and total hip arthroplasty. Am J Orthop (Belle Mead, NJ). 2012; 41: 467-471.

[19] Hays MB, Mayfield JF. Total blood loss in major joint arthroplasty. A comparison of cemented and noncemented hip and knee operations. J Arthroplasty 1988; 3(Suppl): S47-S49.

[20] Parker MJ, Livingstone V, Clifton R, et al. Closed suction surgical wound drainage after orthopaedic surgery. Cochrane Database Syst Rev. 2007; (3): CD001825.

[21] Zhou XD, Li J, Xiong Y, et al. Do we really need closed-suction drainage in total hip arthroplasty? A meta-analysis. Int Orthop. 2013; 37: 2109-2118.

[22] Major T, Bikov A, Holnapy G, et al. Is suction drainage necessary in elective total hip arthroplasty? [Szükség van szívódrainre elektív csípőprotézis-mútétek során?] Orv Hetil. 2016; 157: 11711176. [Hungarian]

[23] Sukeik M, Alshryda S, Haddad FS, et al. Systematic review and meta-analysis of the use of tranexamic acid in total hip replacement. J Bone Joint Surg Br. 2011; 93: 39-46

(Skaliczki Gábor dr., Budapest, Üllői út 26., 1085 e-mail: skaliczki.gabor@med.semmelweis-univ.hu)

A cikk a Creative Commons Attribution 4.0 International License (https://creativecommons.org/licenses/by/4.0/) feltételei szerint publikált Open Access közlemény, melynek szellemében a cikk bármilyen médiumban szabadon felhasználható, megosztható és újraközölhető, feltéve, hogy az eredeti szerző és a közlés helye, illetve a CC License linkje és az esetlegesen végrehajtott módositások feltüntetésre kerülnek. (SID_1) 